Nataša Golubović
Marija Džunić $^{2}$

Srđan Marinković ${ }^{3}$
JEL: A130

DOI: $10.5937 /$ industrija42-5375

UDC: $330.142 .21(497-15)$

Original Scientific Paper

\title{
A Comparative Analysis of Social Capital in the Western Balkan Countries ${ }^{4}$
}

\author{
Article history: \\ Received: 21 January 2014 \\ Sent for revision: 7 March 2014 \\ Received in revised form: 16 April 2014 \\ Accepted: 16 May 2014 \\ Available online: 1 July 2014
}

\begin{abstract}
The aim of this paper is to investigate, on the basis of comparative analysis of social capital development in Western Balkan countries, the availability of different forms of social capital and to identify segments of social capital that represent obstacles to the faster development of these countries. The need for research on social capital in the Balkan countries is conditioned by the fact that apparent differences in the economic performance of these countries, despite more or less similar reform programs, cannot be explained solely by traditional growth factors. Heterogeneity of economic success of these economies is to a great extent determined by the socio-economic structure in which economic institutions are embedded. Balkan countries cannot base their development plans solely on the increase of human and physical capital, but must provide high-quality institutional environment. The results of comparative analysis show the specificity of social capital in the Western Balkan countries, which could in brief be described as a lack of trust in institutions and generalized trust, which stands in the way of improving the economic and institutional efficiency, and strong informal networks (i.e. network capital), which in most cases represent an obstacle to the reform processes.
\end{abstract}

Key words: Social capital, trust, social networks, norms, capital, economics.

\footnotetext{
${ }^{1}$ University of Niš, Faculty of economics, Serbia, natasa.golubovic@eknfak.ni.ac.rs

${ }^{2}$ University of Niš, Faculty of economics, Serbia

${ }^{3}$ University of Niš, Faculty of economics, Serbia

${ }^{4}$ Prepared as a part of the project number 170066, Faculty of economics Niš, financed by the Ministry of science and technological development.
} 
Golubović $N$ et al.: A Comparative Analysis of Social Capital in the Western Balkan...

\title{
Komparativna analiza društvenog kapitala u zemljama zapadnog Balkana
}

\begin{abstract}
Apstrakt: Cilj ovog rada je da se na osnovu komparativne analize razvoja društvenog kapitala u zemljama Zapadnog Balkana utvrdi raspoloživost različitih elemenata društvenog kapitala $i$ ukaže na to koji segmenti društvenog kapitala predstavljaju prepreku bržem razvoju ovih zemalja. Potreba za istraživanjem društvenog kapitala u balkanskim zemljama uslovljena je činjenicom da očigledne razlike u ekonomskim performansama ovih zemalja, uprkos sličnim reformskim programima, nije moguće objasniti tradicionalnim faktorima rasta. Heterogenost ekonomskog uspeha ovih privreda u dobroj meri određena je društveno-ekonomskom strukturom u koju su ekonomske institucije utkane. Balkanske zemlje ne mogu svoje planove razvoja da baziraju samo na povećanju ljudskog i fizičkog kapitala, već moraju da obezbede i kvalitetno institucionalno okruženje. Rezultati komparativne analize ukazuju na specifičnost društvenog kapitala u zemljama Zapadnog Balkana, koja bi u najkraćem mogla da se opiše kao nedostatak poverenja u institucije $i$ generalizovanog poverenja, koji stoji na putu unapređenja ekonomske $i$ institucionalne efikasnosti, kao i snažnim neformalnim mrežama (tzv. mrežnom kapitalu), koje u najvećem broju slučajeva predstavljaju prepreku reformskim procesima.
\end{abstract}

Ključne reči: društveni kapital, poverenje, društvene mreže, norme, kapital, ekonomija.

\section{Introduction}

The concept of social capital, although new in economics, has been for a relatively long time investigated in other social sciences. Although some authors previously pointed out to the phenomenon of resources or capital situated in social relations (Hanifan, 1920), it was only during the 1980s and 1990s, that concept attracted attention of the scientific community (Grootaert \& Bastelaer, 2002). Most authors agree that social networks and social norms are the key elements of social capital. Confidence is perceived as either additional element or as plausible indication of the level of social capital in a community. Social capital exists at all levels of society (family, local community, state). Although it can be regarded as a separate factor of production, the prevailing view is that it should be seen as a factor that determines the allocation and productivity of the basic factors of production such as capital, labor and technology. However, this approach makes empirical investigation of the social capital effects difficult.

When it comes to social networks, we distinguish between bonding, bridging and linking social capital. Bonding social capital represents relationships of 
cooperation and trust within relatively homogeneous groups, such as family and close friends, who generally share the same values. Bridging social capital includes relationships of respect and reciprocity between individuals belonging to different groups with different characteristics, that is, individuals who share different values and experience. Distinction between bonding and bridging ties coincides with Granovetter's (1973) distinction between strong and weak social ties and basically refers to the horizontal voluntary social relationships. Putnam (2008 [1995]) suggests that bonding relationships are important from the standpoint of providing support and assistance in overcoming everyday problems, while bridging ties are important in terms of obtaining a variety of information (e.g., regarding the possibility of employment). Linking social capital is more a macro concept and refers to relationships based on respect and trust, established between actors at different levels in society. For example, relationships between citizens and local government are an example of linking social capital (Woolcock, 1998; Putnam, 2008 [1995]). It refers to vertical relationships - relationships between actors at different levels of power. Bonding and bridging networks are horizontal, and are often referred to as networks of trust, while linking (vertical) are networks of power.

It is also necessary to distinguish between structural and cognitive aspects of social capital. Structural social capital refers to the objective social (formal and informal) structures, such as social networks, social ties, voluntary associations, which promote the exchange of information and other resources. Cognitive social capital is related to the subjective and less tangible elements, such as generally accepted attitudes and norms of behavior, shared values, reciprocity and trust, which regulate behavior of individuals. In this form, social capital is a subjective and vaguer concept (Uphoff, 2000).

Different combinations of individual social capital produce different results. For example, while the poor can have access to certain forms of social capital (we have in mind, primarily, bonding social capital), they often lack the segment that provides access to formal institutions. The lower the level of development of the so-called horizontal social capital, the greater the need for state intervention (the vertical social capital). It is often pointed out that development of vertical forms of social capital crowds out horizontal forms. This assertion is contradicted by the idea of synergy i.e. the view that civic engagement strengthens state institutions while effective state institutions create a favorable environment for civic engagement (Putnam, 1993; Evans, 1996).

The various components of social capital may have different significance in different societies. Relationship between horizontal and vertical social capital is not the same at different levels of society development. For different levels of societal development, optimal combination of horizontal and vertical social capital also differs. This means that only comparative empirical studies of social capital among countries with similar levels of economic development have sense. 
Golubović N et al.: A Comparative Analysis of Social Capital in the Western Balkan...

It should be noted that social capital can affect economic growth and productivity both positively and negatively. The positive effects of social capital refer to the reduction of transaction costs, encouragement of collective action and the diffusion of knowledge and information. Thus, social groups can create high levels of internal solidarity and trust. This type of behavior, in addition to benefits, potentially can bring harm to society. Strong ties within small groups can lead to high barriers to entry for those who do not belong to a group and stimulate rent-seeking behavior by the members of the group. In this case, benefits of the group have been achieved at the expense of the society and may affect the growth of inefficiency of the economy as a whole.

Transition in Central and Eastern Europe has especially spurred debate about the economic role of social capital. In the early years of transition, the emphasis was on the development and harmonization of formal rules as a prerequisite for the construction of an efficient market economy but, the focus very quickly shifted to informal institutions, i.e. those components that make up the "social glue", which we call social capital. Transition increased the need for all those institutions that facilitate the growth of trust in the society, on the one hand, and reduce the cost of all forms of opportunistic behavior, on the other. On the basis of comparative analysis of social capital development in the Western Balkan countries in the period 1994-2010, the aim of this paper is to determine availability of the different elements of social capital and point out to the main directions of their changes during this period. The results of the comparative analysis should identify segments of social capital in the Western Balkan countries that represent obstacle to faster development of these countries, which also indicate in which areas further reforms are needed. Structure of the paper is accommodated to the above mentioned aim. In the first part, based on the existing theoretical and empirical research, different dimensions and components of social capital are analyzed. In the second part, we examine the issues related to the measurement of social capital (availability of appropriate indicators in public databases, extent to which these indicators cover different aspects of social capital). The third part presents a methodological framework of analysis. In the fourth section, the main results of the comparative analysis of development of social capital in the Western Balkan countries were presented.

\section{Measurement of social capital - literature review}

In order to ensure comparability of the results of empirical studies, a number of authors have followed the Putnam (1993) approach, which distinguishes between three elements of social capital - trust, social norms and social networks (Narayan \& Cassiddy 2001; Rothstein 2001; Oorschot \& Arts, 2005). 
Golubović N et al.: A Comparative Analysis of Social Capital in the Western Balkan...

Quantifying the level of trust requires interviewing individuals about their expectations and experiences when it comes to behavior based on trust. Respondents are asked a number of questions related to trust in individuals and the various political and social institutions. It poses certain problems, starting with the fact that the answer depends on the way the question was asked, to the lack of consistent data for many countries and time periods. At the same time, we should take into account the fact that survey questions have to adapt to the specific social, economic and cultural environment. As an indicator of the level of social capital in society, investigation of trust is often cited as an example of using measurement techniques when data of adequate quality and quantity do not exist. Namely, the subjective evaluation of trust of the respondents is used as an indicator of social capital, and then through a sophisticated regression analysis associated with indicators of national economic performances, producing precise results that include a few decimal points. Indicators of the level of trust in most empirical studies of social capital are based on the idea that the level of trust can be determined on the basis of "subjective beliefs of economic actors that other actors or groups of actors will behave in a certain manner" (Gambetta, 1998, p. 217). However, trust in other actors does not prevent opportunistic behavior. In other words, indicators of trust derived from questionnaires are "micro" concept because they depend on the individual's perception of their social environment, and that perception depends on the position the interviewed individual has in the social structure and is not indicative of the actual behavior of other actors.

The most commonly used indicator of generalized trust is obtained using data from questionnaires, received as a response to the following question: "Generally speaking, would you say that most people can be trusted or that you can never be too careful with people?" Another approach in measuring trust is based on questions related to specific situations, that is, an individual is asked about how he would behave (or how he expects other actors would behave) if, for example, he finds a lost wallet. Soroka et al. (2003) point out that the answer to the first question is conditioned by cultural norms, while the answer to the second question depends on the context and life experience. It is necessary to point out to difference between the attitudes of individuals about trust and actual behavior. Since it is difficult to quantify the actual behavior, responses from the questionnaires usually provide information about attitudes of individuals in relation to trust. Quite another issue is whether these data give us insight into the actual behavior of individuals. In terms of institutional trust, the question is whether all institutions are of equal importance from the standpoint of generating social capital (institutions of the welfare state is considered the most important (see Rothstein \& Stolle, 2002)).

Using the density of network of civic associations as indicators of network dimension of social capital consists of determining the number of associations and their members, as well as measuring different aspects of membership 
Golubović N et al.: A Comparative Analysis of Social Capital in the Western Balkan...

(such as internal heterogeneity) and functioning of institutions (degree of democracy in decision-making). Which associations will be included in the analysis depends on the specific conditions in each country: the agrarian unions may be important in one country, credit and savings associations in the second, associations of parents and teachers in the third, and so on. One of the key issues in terms of quantifying the network dimension of social capital refers to the dilemma whether all types of organizations and associations are of the same importance or not. According to Putnam (Putnam, 1995), it does not matter so much in which type of organization individuals are involved, meaning that research of this aspect of social capital must include all civic organizations and associations. On the other hand, there are opinions that religious organizations should be excluded when calculating the membership index because of their hierarchical nature. Some authors, besides neglecting membership in religious organizations, also neglect membership in trade unions, since many countries do not consider membership in trade unions and religious organizations as voluntary choice, but a matter of tradition or administrative practices. Distinction is often made between so-called Olson-type and Putnam-type organizations. Organizations of Olson-type include professional associations, political parties and trade unions, while organizations of Putnam-type include sports, youth, educational and cultural organizations. It is believed that organizations of Putnam-type include more social interactions of individuals with different experiences, which helps build trust and norms of cooperation, while the organizations of Olson-type are prone to rent-seeking (Knack \& Keefer, 1997). Finally, the distinction between active and passive participation is considered to be very important. Active participation encourages people to cooperate, while the passive participation is a sign of a commitment to community participation and civil society (Oorschot \& Arts, 2005).

Another problem with the quantification of social capital relates to the aggregation. Although social capital is considered as community characteristic, indicators of social capital are usually obtained by interviewing individuals. A simple process of aggregation ignores the fact that society may consist of many sub-groups which are characterized by a high level of internal social capital, lacking at the same time that segment of social capital based on the relationships between different groups. There may be a high level of social capital within the group that benefits its members, but the absence of bridging connections between groups limits their access to other resources. Only bridging ties open economic opportunities for those who belong to the less powerful or marginalized groups. They contribute to social cohesion, a critical element of social stability and economic prosperity in the long run. Social cohesion requires not only a high level of social capital within the group, but also cross-cutting ties between the groups. The social capital of the community cannot be a simple sum of individual social capital, bearing in mind the importance of external effects (Paldam 2000; Glaeser et al, 2000). 
It should be pointed out that the measurement of social capital and quantifying its contribution to economic growth are hampered by different social, cultural, political and institutional environment in different countries. Social capital based on trust and cooperation can contribute to the explanation of economic performance and growth in relatively stable societies with stable institutional and policy framework. In transition countries, where the institutional and political framework of a market economy is in its infancy and where the changes of political situation strongly affect trust in institutions, trust could significantly change without a clear connection to the quality of the institutional environment and economic performances.

\section{Methodological framework of the research}

Assuming that various components of social capital can produce different effects in societies on different levels of social and economic development, comparative analyses of the level of social capital are usually performed on a sample of countries with a similar level of development. Selected countries for this study are the Western Balkan countries: Albania, Bosnia and Herzegovina, Macedonia, Montenegro, Croatia and Serbia. Other countries of the region that have already become members of the EU during period which is subject of this study were not taken into account (Bulgaria and Romania).

The main criterion for selecting the empirical database was the availability of data and their comparability in different periods. Following the example of many empirical studies of social capital, two databases have been selected: World Values Survey and European Values Study, as the most comprehensive databases, comprising data on attitudes of individuals and their social activities in different areas of human interest - religion, politics, economic and social life. Conducted throughout the world and based on representative samples, opinion polls since 1981 to date, reveal current trends and changes in the basic social values, their variations across countries and over time. Data are available in the form of opinion poll answers based on standard questionnaires, collected during several waves of research. Due to the fact that the surveys in Balkan countries have been conducted since the mid-1990s, data on the citizens' attitudes towards the social and political changes they have witnessed are available in the third (1994-1999), the fourth (1999-2004) and the fifth (2005-2008) wave of World Values Survey (WVS, 2009) and the fourth wave of European Values Study, completed in 2010 (EVS, 2011). The sixth wave of research (2010-2014) has not yet been completed, which means that available data allow comparative analysis of social capital in the Balkans from 1994 to 2010. 
Golubović N et al.: A Comparative Analysis of Social Capital in the Western Balkan...

For the purpose of collecting data, both studies apply systematized and standardized approach based on interviewing a representative sample of respondents in each of the countries covered by the survey. The surveys use forms of the stratified sample in order to obtain representative national samples. All the surveys were carried out on representative samples of at least 1000 people older than 18 years. Individuals were interviewed on the base of uniformly structured questionnaires. Data collection was entrusted to professional organizations that have used either 'face to face' techniques of interviewing or telephone interviews for remote areas. It is important to note that the formulation of the questions in the different surveys was the same, which allows the comparison of data obtained. The use of identical questionnaires and data collection methodology allows us to use the data of the World Values Survey for the third and fourth wave of research (published in 2000 and 2005), and the fourth wave of European Values Study (completed in 2010), in order to provide full data coverage.

Taking into account the historical and social diversities, the comparative analysis of social capital in the Western Balkan countries will include an overview of the various dimensions and components of social capital in the selected sample, in three consecutive periods. Following Putnam's approach, the analysis will include trust, social norms and social networks. Structural aspect of social capital will be analyzed through the inclusion of individuals in formal social networks (different social organizations), both in the form of membership in these organizations as well as active participation of individuals by performing unpaid voluntary work. On the other hand, individuals' participation in informal networks will be measured by the intensity of bridging social ties (with friends, colleagues and people in the immediate environment) and bonding social ties (relying on close family ties). The cognitive aspect of social capital will be studied through the analysis of different types of trust: generalized (which implies a degree of trust in people in general) and trust in institutions, measured by the degree to which respondents can rely on a variety of formal institutions. The level of satisfaction with the development of democracy will be used as an additional measure of institutional trust. Cognitive aspect of social capital will also include the norms of social behavior, in terms of the justification of certain social actions. Finally, in order to fully illustrate the participation of individuals in social life, indicators of political engagement will be presented. The limited availability of data in different periods, as well as described problems of the quantification of social capital, requires caution when interpreting data. The aim of the comparative analysis of different aspects of social capital is to present the level and characteristics of the available social capital in the Western Balkans, as well as to point to the changes in certain segments of social capital during significant social and economic changes in the period 1994-2010. 
Golubović N et al.: A Comparative Analysis of Social Capital in the Western Balkan...

\section{Results and discussion}

\subsection{Trust in the Western Balkan countries}

Most surveys obtain data on the level of trust by asking the standard question: "Generally speaking, would you say that most people can be trusted or that you can't be too careful in dealing with people?". Possible answers are: 1 Most people can be trusted; 2 - Can't be too careful; 3 - I don't know. The measure of trust obtained this way is the percentage of the population in a country that believes that people in general can be trusted.

Data about the level of generalized trust in the Balkan countries for the period from 1994-2010 are presented in Table 1, as the percentage of respondents who believe that people can be trusted.

Table 1. The level of generalized trust in the Balkan countries

\begin{tabular}{|l|c|c|c|}
\hline Country & $\mathbf{2 0 0 0}$ & $\mathbf{2 0 0 5}$ & $\mathbf{2 0 1 0}$ \\
\hline Albania & $27.0 \%$ & $24.4 \%$ & $10.6 \%$ \\
\hline B and $\mathrm{H}$ & $28.3 \%$ & $15.8 \%$ & $26.6 \%$ \\
\hline Serbia & $28.4 \%$ & $18.3 \%$ & $11.8 \%$ \\
\hline Macedonia & $8.2 \%$ & $13.5 \%$ & $20.1 \%$ \\
\hline Montenegro & $30.4 \%$ & $32.9 \%$ & $24.9 \%$ \\
\hline Croatia & $25.1 \%$ & $18.4 \%$ & $19.7 \%$ \\
\hline Balkan average & $\mathbf{2 4 . 6 \%}$ & $\mathbf{2 0 . 6 \%}$ & $\mathbf{1 8 . 9 \%}$ \\
\hline OECD ${ }^{5}$ average & $45 \%^{6}$ & $43.7 \%^{\prime}$ & $54.18^{8}$ \\
\hline
\end{tabular}

Source: WVS (2009), EVS (2011)

Empirical data indicate a low level of average trust in the Balkan countries. In addition, observing data from different time periods points to a continuous decline of trust. Before the year of 2000 , a quarter of respondents were willing to trust the people in their environment, while over the next five years, only one-fifth of the respondents maintained that attitude. In the third period, the average percentage of trusting individuals was less than $20 \%$. The only exception to this trend is Macedonia, as the only country where the level of trust

\footnotetext{
${ }^{5}$ The sample of OECD countries only includes European countries that have been OECD members in the observed periods.

${ }^{6}$ Data for 7 European countries OECD members has been used from World Values Survey for the period 1994-1999: Finland, Western Germany, Norway, Spain, Sweden, Switzerland and Great Britain.

${ }^{7}$ Data for 7 European countries OECD members has been used from World Values Survey for the period 1999-2004: Belgium, Denmark, Finland, Western Germany, Spain, Sweden, Great Britain.

${ }^{8}$ Data for 7 European countries OECD members has been used from European Values Study for the period 2005-2010: Finland, Great Britain, Spain, Norway, Sweden, Switzerland, Germany.
} 
Golubović N et al.: A Comparative Analysis of Social Capital in the Western Balkan...

has increased in the last decade. During the past 5 years, a significant increase in trust was recorded in Bosnia and Herzegovina, while trust in Croatia increased for modest $1.3 \%$. The lowest levels of trust according to the latest measurements are measured in Albania (10.6\%) and Serbia (11.8\%), where the level of trust decreased 2.5 times in a decade's time.

In order to further illustrate the state of trust in the Balkan countries, the average generalized trust in the Balkans is compared to the average level of trust in the developed European countries (OECD members). The results indicate a large gap in the level of trust between these two groups of countries. Although the average level of trust in the Balkan countries is more than $20 \%$ lower compared to the developed European economies in all periods, the difference between them has tripled over recent years. The largest gap is observed by comparing the level of trust in the Balkan countries with traditionally high trust in the Scandinavian countries, where over $65 \%$ of respondents are willing to trust people (EVS, 2011). In developed European countries there is a growing trend of the average level of trust, which is another important difference in relation to the Balkan countries. Given data imply the consistency of the levels of trust within the group of observed countries, indicating similar conditions of social capital accumulation, along with the fact that the level of trust in the Balkan countries lags significantly behind the level of trust in the developed market economies. Given the fact that the Balkan countries belong to the group of post-socialist countries, some theorists (Paldam \& Svendsen, 2000, 2001; Adam et al., 2004) claim this gap was caused by the breakdown of social capital in the socialist regime, in which all kinds of social interactions outside the immediate networks of family and friendship relations were discouraged. However, since more than a decade has passed since the change of the political systems in the surveyed countries, and the level of trust has not increased, these theories are called into question. According to the social capital theory, low level of trust has a negative impact on economic efficiency by increasing transaction costs and reducing the volume of economic transactions.

An important indicator of social capital in a country is also a degree of citizens' confidence in the institutions of the system. According to some authors, trust in institutions reflects the strength of a state itself (Rothstein, 2001), making an integral element of vertical social capital. Indicator of institutional trust is based on the scales of assessment of confidence (grades from 1 - very high confidence to 4 - no confidence) in different institutions. A total of 18 institutions were included in World Values Survey and European Values Study, which can be grouped into political institutions (government, parliament, political parties), control institutions (the media, the civil sector) and neutral institutions (police, armed forces, justice system, health, education). Assuming that not all state institutions have equal importance from the aspect of social capital, comparative analysis will focus on trust in political institutions, armed forces, the police and the justice system, as well as the church. Tables 2, 3 and 4 
Golubović N et al.: A Comparative Analysis of Social Capital in the Western Balkan...

show data on confidence in various institutions in the Balkan countries for three consecutive periods, as a percentage of the respondents who expressed "a great deal" and "quite a lot" confidence in these institutions (grades 1 and 2).

Table 2. Trust in institutions in the Balkan countries (2000)

\begin{tabular}{|l|c|c|c|c|c|c|c|}
\hline \multicolumn{1}{|c|}{ Country } & Government & Parliament & $\begin{array}{c}\text { Pol. } \\
\text { parties }\end{array}$ & $\begin{array}{c}\text { Justice } \\
\text { system }\end{array}$ & Police & Church & $\begin{array}{c}\text { Armed } \\
\text { forces }\end{array}$ \\
\hline Albania & $41.4 \%$ & $60.7 \%$ & $22.9 \%$ & $58.5 \%$ & $73.0 \%$ & $53.6 \%$ & $58.1 \%$ \\
\hline B and H & $70.8 \%$ & $56.7 \%$ & $46.6 \%$ & $70.5 \%$ & $80.1 \%$ & $72.2 \%$ & $88.0 \%$ \\
\hline $\begin{array}{l}\text { Serbia and } \\
\text { Montenegro }\end{array}$ & $37.4 \%$ & $34.0 \%$ & $18.4 \%$ & $46.8 \%$ & $46.1 \%$ & $38.3 \%$ & $61.6 \%$ \\
\hline Macedonia & $20.1 \%$ & $15.7 \%$ & $11.4 \%$ & $24.4 \%$ & $26.6 \%$ & $31.1 \%$ & $38.7 \%$ \\
\hline Croatia & $52.2 \%$ & $41.8 \%$ & $22.4 \%$ & $51.4 \%$ & $60.6 \%$ & $57.4 \%$ & $78.6 \%$ \\
\hline Average trust & $45.2 \%$ & $41.8 \%$ & $24.7 \%$ & $51.0 \%$ & $57.5 \%$ & $50.7 \%$ & $66.3 \%$ \\
\hline
\end{tabular}

Table 3. Trust in institutions in the Balkan countries (2005)

\begin{tabular}{|l|c|c|c|c|c|c|c|}
\hline \multicolumn{1}{|c|}{ Country } & Government & Parliament & $\begin{array}{c}\text { Pol. } \\
\text { parties }\end{array}$ & $\begin{array}{c}\text { Justice } \\
\text { system }\end{array}$ & Police & Church & $\begin{array}{c}\text { Armed } \\
\text { forces }\end{array}$ \\
\hline Albania & $57.4 \%$ & $45.2 \%$ & $29.4 \%$ & $/$ & $65.0 \%$ & $66.4 \%$ & $56.6 \%$ \\
\hline B and H & $29.5 \%$ & $20.2 \%$ & $14.5 \%$ & $/$ & $63.6 \%$ & $49.6 \%$ & $60.7 \%$ \\
\hline $\begin{array}{l}\text { Serbia and } \\
\text { Montenegro } 10\end{array}$ & $32.6 \%$ & $27.9 \%$ & $19.9 \%$ & $/$ & $43.8 \%$ & $50.6 \%$ & $63.3 \%$ \\
\hline Macedonia & $10.9 \%$ & $7.0 \%$ & $9.5 \%$ & $/$ & $51.1 \%$ & $46.2 \%$ & $54.5 \%$ \\
\hline Croatia & $/$ & $22.5 \%$ & $/$ & $35.3 \%$ & $53.1 \%$ & $64.3 \%$ & $66.0 \%$ \\
\hline Average trust & $32.4 \%$ & $24.8 \%$ & $18.4 \%$ & $35.3 \%$ & $53.3 \%$ & $54.3 \%$ & $60.7 \%$ \\
\hline
\end{tabular}

Table 4. Trust in institutions in the Balkan countries (2010)

\begin{tabular}{|l|c|c|c|c|c|c|c|}
\hline \multicolumn{1}{|c|}{ Country } & Government & Parliament & $\begin{array}{c}\text { Pol. } \\
\text { parties }\end{array}$ & $\begin{array}{c}\text { Justice } \\
\text { system }\end{array}$ & Police & Church & $\begin{array}{c}\text { Armed } \\
\text { forces }\end{array}$ \\
\hline Albania & $26.5 \%$ & $31.8 \%$ & $21.6 \%$ & $25.1 \%$ & $59.3 \%$ & $50.4 \%$ & $50.7 \%$ \\
\hline B and H & $20.8 \%$ & $26.0 \%$ & $12.2 \%$ & $38.9 \%$ & $54.9 \%$ & $59.1 \%$ & $43.7 \%$ \\
\hline Serbia & $13.0 \%$ & $12.3 \%$ & $6.4 \%$ & $24.5 \%$ & $34.5 \%$ & $60.9 \%$ & $41.1 \%$ \\
\hline Macedonia & $51.8 \%$ & $48.8 \%$ & $34.3 \%$ & $37.7 \%$ & $58.8 \%$ & $75.9 \%$ & $73.6 \%$ \\
\hline Montenegro & $38.8 \%$ & $36.2 \%$ & $16.0 \%$ & $43.9 \%$ & $44.3 \%$ & $63.6 \%$ & $26.8 \%$ \\
\hline Croatia & $13.8 \%$ & $11.7 \%$ & $7.2 \%$ & $19.5 \%$ & $36.6 \%$ & $54.3 \%$ & $46.8 \%$ \\
\hline $\begin{array}{l}\text { Average } \\
\text { trust }\end{array}$ & $27.4 \%$ & $27.8 \%$ & $16.3 \%$ & $31.6 \%$ & $48.1 \%$ & $60.7 \%$ & $47.1 \%$ \\
\hline
\end{tabular}

Source: WVS (2009), EVS (2011)

If trust in the individual institutions is interpreted as an indicator of citizens' public support for the state, the results indicate that, the Balkan countries

\footnotetext{
${ }^{9}$ In World Values Survey database some data for Serbia and Montengro are integrated, therefore they are here presented in the integrated form.

${ }^{10}$ In World Values Survey database some data for Serbia and Montengro are integrated, therefore they are here presented in the integrated form.
} 
Golubović $N$ et al.: A Comparative Analysis of Social Capital in the Western Balkan...

have faced a continuous decline of their citizens' support over the last 15 years. The dynamics of this indicator over the three 5 -year periods shows that there is a decline in the average trust in all institutions.

According to the degree of confidence, institutions can be grouped as follows: citizens have a minimum of trust in political institutions, where political parties stand out as institutions with the least confidence. Citizens express slightly higher degree of confidence in the justice system and the police, while the church and the army are the institutions with the highest degree of citizens' trust. In the last observed period, only $15 \%$ to $30 \%$ of citizens express confidence in political institutions. A higher level of confidence is expressed in the judicial system, the police and the army (approximately 30\% to 50\%), while the church is the only institution where the trust levels exceed $60 \%$. The paradox here is that during the political transformation of the post-socialist countries, citizens had the least trust in institutions that had crucial importance for the development of representative democracy (political parties, parliament, government), while hierarchical institutions - the church and the army enjoyed the most of confidence. So, the institutions whose transformation was necessary for the development of democracy and reforms had the largest legitimacy, while the institutions responsible for the implementation of the reforms had the least public support.

An additional indicator of institutional trust, which could indicate if the lack of citizens' confidence in the institutions was determined by the degree of development of democracy and the results of the current political leadership, is the citizens' satisfaction with the development of democracy in the country.

Table 5: Satisfaction with democracy

\begin{tabular}{|l|c|c|}
\hline Country & $\mathbf{2 0 0 5}$ & $\mathbf{2 0 1 0}$ \\
\hline Albania & $19.2 \%$ & $19.2 \%$ \\
\hline B and $\mathrm{H}$ & $24.3 \%$ & $25.4 \%$ \\
\hline Serbia & $33.1 \%$ & $19.7 \%$ \\
\hline Macedonia & $18.5 \%$ & $42.4 \%$ \\
\hline Montenegro & $/$ & $37.3 \%$ \\
\hline Croatia & $/$ & $25.7 \%$ \\
\hline Average & $25.7 \%$ & $28.3 \%$ \\
\hline
\end{tabular}

Source: WVS (2009), EVS (2011)

Table 5 shows the percentage of respondents who answered the question: "Are you very satisfied, satisfied, not very satisfied or not at all satisfied with the development of democracy in our country?" with "very satisfied" or "satisfied". Due to incomplete data, only the second and third periods are presented. Despite the modest increase in satisfaction with democracy, barely a quarter of the population of the Balkan countries positively assessed the democratic process in their countries. These results indicate that it is difficult 
Golubović N et al.: A Comparative Analysis of Social Capital in the Western Balkan...

to separate the functioning of the institutions from the political system in the Balkans, since these countries have not yet reached stabile democracy. This indicates that one of the causes of low social capital may be a lack of political maturity of the transformed countries, in terms of institutions depending on the current incumbent party (Milošević, 2012).

\subsection{Social capital within formal and informal social networks}

The network dimension of social capital is studied through the participation of individuals in the formal and informal networks. Measuring the degree of participation in formal networks is based on the questions about belonging to various voluntary organizations. As the distinction between active and passive participation in voluntary organizations is considered very important, incomplete data for the Balkan countries, unpaid voluntary work in social organizations will be used as an indicator of active participation. Table 6 presents the citizens' participation in formal social networks in the Balkans, in two observed periods, as a percentage of respondents who identified themselves as belonging to these organizations.

The measurement of the intensity of citizens' participation is based on the assumption that not all social organizations are equally significant in terms of the formation of social capital, and therefore various organizations in the table are sorted in specific types of organizations (Putnam, Olson and others). The intensity of social participation in the Balkan countries can be assessed as low, according to a small number of organizations with over $10 \%$ of participants.

Comparing the average citizens' participation in two consecutive periods shows that social participation almost invariably decreases in all countries and all types of organizations. The exception is increased participation of Croatian citizens in organizations of Putnam-type, as well as the same level of participation maintained in other organizations in Serbia and Montenegro (as it is a very low percentage of participation, it cannot be evaluated as an important step in encouraging social participation).

The relatively high level of citizens' participation is recorded in sports organizations (average $9.46 \%$ ), political parties (8.87\%) and trade unions $(7.71 \%)$, while the lowest participation is in human rights organizations $(2.08 \%)$. On average, citizens of the Balkan countries more intensively participate in organizations of Olson- type $(6.98 \%)$ compared to Putnam-type organizations. The highest percentages of participation were measured in Albania, and the lowest in Bosnia and Herzegovina. Bearing in mind that the Balkan countries belong to the post-socialist economies, the participation in community organizations in these countries must be considered with respect to the specifics of social participation in the pre-transition period. 
Golubović $N$ et al.: A Comparative Analysis of Social Capital in the Western Balkan...

Gradual transformation of forms of social participation has been taking place in these countries, from the mandatory memberships in political parties and trade unions, to the voluntary participation in independent organizations with their own autonomy and identity. In the majority of countries, political factors have a great impact on all forms of social activity, which explains the high level of citizen involvement in Olson-type organizations.

Table 6: Belonging to voluntary organizations (in \%)

\begin{tabular}{|c|c|c|c|c|c|c|c|c|c|c|c|c|c|}
\hline \multirow{2}{*}{$\begin{array}{l}\mathrm{T} \\
\mathrm{y} \\
\mathrm{p} \\
\mathrm{e}\end{array}$} & \multirow{2}{*}{ Period } & \multicolumn{2}{|c|}{ Albania } & \multicolumn{2}{|c|}{$\mathrm{B}$ and $\mathrm{H}$} & \multicolumn{2}{|c|}{ Croatia } & \multicolumn{2}{|c|}{ Macedonia } & \multicolumn{2}{|c|}{ Montenegro } & \multicolumn{2}{|c|}{ Serbia } \\
\hline & & 2005 & 2010 & 2005 & 2010 & 2005 & 2010 & 2005 & 2010 & 2005 & 2010 & 2005 & 2010 \\
\hline $\begin{array}{l}P \\
u\end{array}$ & $\begin{array}{l}\text { Sports / } \\
\text { recreation }\end{array}$ & 10.6 & 9.7 & 11.3 & 4.9 & 11.9 & 13.2 & 12.9 & 8.4 & 9.6 & 4.5 & 9.6 & 6.9 \\
\hline $\begin{array}{l}\mathrm{t} \\
\mathrm{n}\end{array}$ & $\begin{array}{l}\text { Cultural } \\
\text { Education }\end{array}$ & 13.5 & 4.6 & 4.1 & 1.9 & 5.6 & 8.6 & 11.7 & 7.5 & 5.8 & 3.0 & 5.8 & 4.4 \\
\hline $\begin{array}{l}a \\
m\end{array}$ & $\begin{array}{l}\text { Youth } \\
\text { work }\end{array}$ & 12.3 & 8.9 & 2.1 & 1.1 & 2.1 & 4.0 & 5.1 & 5.8 & 1.9 & 2.6 & 1.9 & 2.0 \\
\hline & Average & 12.1 & 7.7 & 5.8 & 2.6 & 6.5 & 8.6 & 9.9 & 7.2 & 5.8 & 3.4 & 5.8 & 4.4 \\
\hline $\mathrm{O}$ & Trade unions & 9.4 & 7.7 & 6.8 & 2.2 & 10.6 & 6.0 & 6.0 & 4.1 & 14.7 & 4.6 & 14.7 & 5.7 \\
\hline $\begin{array}{l}1 \\
s\end{array}$ & \begin{tabular}{|l|} 
Professional \\
associations
\end{tabular} & 10.8 & 7.2 & 2.4 & 0.9 & 3.2 & 2.9 & 6.7 & 4.5 & 4.0 & 2.6 & 4.0 & 3.6 \\
\hline $\begin{array}{l}0 \\
\mathrm{n}\end{array}$ & \begin{tabular}{|l|} 
Political \\
parties
\end{tabular} & 14.5 & 11.0 & 7.1 & 4.4 & 3.7 & 6.9 & 11.5 & 11.4 & 12.3 & 4.6 & 12.3 & 6.7 \\
\hline & Average & 11.6 & 8.6 & 5.4 & 2.5 & 5.8 & 5.3 & 8.1 & 6.7 & 10.3 & 3.9 & 10.3 & 5.3 \\
\hline & $\begin{array}{l}\begin{array}{l}\text { Religious or } \\
\text { church }\end{array} \\
\end{array}$ & 20.4 & 12 & 8.0 & 3.9 & 12.9 & 10.3 & 10.9 & 4.0 & 3.0 & 3.4 & 3.0 & 3.3 \\
\hline & Environment & 10.4 & 6.0 & 1.9 & 0.9 & 2.1 & 3.1 & 4.9 & 4.7 & 2.5 & 2.2 & 2.5 & 2.4 \\
\hline & $\begin{array}{l}\text { Human } \\
\text { rights }\end{array}$ & 6.4 & 5.3 & 0.2 & 0.4 & 0.7 & 0.7 & 3.4 & 0.3 & 0.8 & 1.6 & 0.8 & 1.1 \\
\hline O & Welfare & 13.6 & 8.2 & 1.5 & 1.2 & 2.1 & 3.0 & 7.2 & 2.5 & 3.6 & 2.6 & 3.6 & 2.3 \\
\hline $\begin{array}{l}\mathrm{h} \\
\mathrm{e}\end{array}$ & $\begin{array}{l}\text { Local com- } \\
\text { munity }\end{array}$ & 11.6 & 6.5 & 1.1 & 0.6 & 1.6 & 1.8 & 5.6 & 3.8 & 0.6 & 1.4 & 0.6 & 2.1 \\
\hline$r$ & \begin{tabular}{|l} 
Women's \\
groups
\end{tabular} & 13.6 & 7.4 & 2.7 & 2.1 & 2.2 & 2.9 & 6.0 & 2.7 & 1.8 & 2.7 & 1.8 & 1.8 \\
\hline & \begin{tabular}{|l|} 
Peace \\
movements
\end{tabular} & 7.2 & 5.1 & 0.2 & 0.6 & 1.1 & 1.0 & 5.4 & 1.0 & 0.4 & 1.5 & 0.4 & 1.1 \\
\hline & \begin{tabular}{|l|} 
Voluntary \\
health
\end{tabular} & 12.9 & 6.5 & 2.5 & 0.9 & 3.1 & 2.6 & 7.8 & 2.7 & 1.8 & 2.4 & 1.8 & 2.8 \\
\hline & Other groups & 5.2 & 5.6 & 3.1 & 1.1 & 4.4 & 4.3 & 7.7 & 4.4 & 3.9 & 1.6 & 3.9 & 1.4 \\
\hline & Average & 11.3 & 7.0 & 2.4 & 1.3 & 3.4 & 3.3 & 6.5 & 2.9 & 2.0 & 2.2 & 2.0 & 2.0 \\
\hline
\end{tabular}

Source: WVS (2009), EVS (2011) 
Golubović N et al.: A Comparative Analysis of Social Capital in the Western Balkan...

Indicator of social participation in formal organizations is even more unfavorable when viewed through a form of active participation of citizens, i.e. performing unpaid voluntary work (Table 7 ). In addition to the measured slight increase of participation in Serbia, active participation intensity is reduced in all other countries and all types of organizations. The data in the table show that citizens actively participate in a greater percentage only in sports organizations, and in some countries in political parties (Albania, Macedonia). The present findings clearly indicate that the citizens of Balkan countries are characterized by a low level of participation in formal social organizations.

Table 7: Voluntary unpaid work in organizations (in \%)

\begin{tabular}{|c|c|c|c|c|c|c|c|c|c|c|c|c|c|}
\hline \multirow{2}{*}{$\begin{array}{l}\mathrm{T} \\
\mathrm{y} \\
\mathrm{p} \\
\mathrm{e}\end{array}$} & \multirow{2}{*}{ Period } & \multicolumn{2}{|c|}{ Albania } & \multicolumn{2}{|c|}{$\mathrm{B}$ and $\mathrm{H}$} & \multicolumn{2}{|c|}{ Croatia } & \multicolumn{2}{|c|}{ Macedonia } & \multicolumn{2}{|c|}{ Montenegro } & \multicolumn{2}{|c|}{ Serbia } \\
\hline & & 2005 & 2008 & 2005 & 2008 & 2005 & 2008 & 2005 & 2008 & 2005 & 2008 & 2005 & 2008 \\
\hline$P$ & $\begin{array}{l}\text { Sports / } \\
\text { recreation }\end{array}$ & 8.2 & 6.0 & 7.2 & 2.4 & 6.7 & 3.2 & 8.7 & 6.1 & 4.3 & 2.0 & 4.3 & 3.3 \\
\hline II & \begin{tabular}{|l} 
Cultural \\
Education
\end{tabular} & 9.8 & 7.8 & 2.7 & 0.7 & 2.7 & 3.6 & 7.1 & 4.0 & 1.6 & 1.3 & 1.6 & 2.1 \\
\hline $\begin{array}{l}a \\
m\end{array}$ & \begin{tabular}{|l} 
Youth \\
Work
\end{tabular} & 8.8 & 6.1 & 1.5 & 0.2 & 1.5 & 1.6 & 3.4 & 3.5 & 0.5 & 1.5 & 0.5 & 1.1 \\
\hline & Average & 8.9 & 6.6 & 3.8 & 1.1 & 3.6 & 2.8 & 6.4 & 4.5 & 2.1 & 1.6 & 2.1 & 2.2 \\
\hline $\mathrm{O}$ & Trade unions & 4.4 & 5.9 & 1.9 & 0.4 & 3.7 & 0.9 & 1.7 & 2.0 & 1.6 & 1.6 & 1.6 & 1.6 \\
\hline s & $\begin{array}{l}\text { Professional } \\
\text { associations }\end{array}$ & 7.2 & 5.7 & 1.1 & 0.3 & 2.2 & 1.1 & 2.8 & 2.9 & 1.2 & 1.6 & 1.2 & 1.7 \\
\hline n & \begin{tabular}{|l} 
Political \\
parties
\end{tabular} & 11.4 & 8.9 & 3.1 & 1.7 & 1.6 & 2.4 & 8.1 & 7.2 & 2.0 & 1.6 & 2.0 & 2.9 \\
\hline & Average & 7.7 & 6.8 & 2.0 & 0.8 & 2.5 & 1.5 & 4.2 & 4.0 & 1.6 & 1.6 & 1.6 & 2.1 \\
\hline & $\begin{array}{l}\begin{array}{l}\text { Religious or } \\
\text { church }\end{array} \\
\end{array}$ & 14.6 & 9.4 & 4.5 & 1.6 & 5.3 & 4.6 & 8.5 & 2.9 & 1.5 & 1.6 & 1.5 & 1.2 \\
\hline & Environment & 7.0 & 4.7 & 1.5 & 0.4 & 1.5 & 1.6 & 3.1 & 3.0 & 1.3 & 1.3 & 1.3 & 1.5 \\
\hline & $\begin{array}{l}\text { Human } \\
\text { rights }\end{array}$ & 2.4 & 4.8 & 0.3 & 0.1 & 0.4 & 0.2 & 2.0 & 0.5 & 0.3 & 1.1 & 0.3 & 0.5 \\
\hline $\mathrm{O}$ & Welfare & 10.8 & 6.6 & 1.1 & 0.5 & 1.1 & 1.2 & 4.8 & 1.5 & 2.2 & 1.2 & 2.2 & 1.4 \\
\hline h & $\begin{array}{l}\text { Local com- } \\
\text { munity }\end{array}$ & 7.7 & 5.3 & 1.2 & 0.2 & 1.0 & 0.5 & 3.3 & 2.7 & 0.3 & 1.5 & 0.3 & 1.3 \\
\hline e & \begin{tabular}{|l} 
Women's \\
groups
\end{tabular} & 9.3 & 5.7 & 1.8 & 1.0 & 2.2 & 0.9 & 3.9 & 2.1 & 0.8 & 1.8 & 0.8 & 1.0 \\
\hline & \begin{tabular}{|l|} 
Peace \\
movements
\end{tabular} & 3.4 & 4.3 & 0.2 & 0.3 & 0.6 & 0.2 & 2.8 & 0.9 & 0.3 & 1.0 & 0.3 & 0.7 \\
\hline & $\begin{array}{l}\text { Voluntary } \\
\text { health }\end{array}$ & 8.3 & 5.0 & 1.8 & 0.5 & 1.6 & 1.2 & 4.8 & 1.8 & 1.5 & 1.4 & 1.5 & 1.9 \\
\hline & Other groups & I & 4.6 & l & 0.4 & 3.1 & 2.9 & 1 & 2.7 & I & 0.9 & I & 0.9 \\
\hline & Average & 7.9 & 5.6 & 1.6 & 0.6 & 1.9 & 1.5 & 4.2 & 2.0 & 1.0 & 1.3 & 1.0 & 1.2 \\
\hline
\end{tabular}

Source: WVS (2009), EVS (2010) 
Golubović $N$ et al.: A Comparative Analysis of Social Capital in the Western Balkan...

In addition to the formal participation of individuals in voluntary organizations, an important element of social capital is the intensity of informal social contacts. Social activism in informal networks is divided into bridging and bonding social ties. Bridging ties are expressed through the frequency of spending time with friends, the importance of friends in life and spending time with different social groups. Bonding ties refer to close relatives and are measured with the following questions: the importance of family in life, preparedness to help immediate family and concern for the family. Tables 8 and 9 show the percentages of respondents that consider friends, acquaintances and family members "very important" in their lives. The intensity of bonding ties is further illustrated by the degree of concern for the family.

Table 8: Bridging social capital - friends important in life

\begin{tabular}{|l|c|c|c|}
\hline Country & $\mathbf{2 0 0 0}$ & $\mathbf{2 0 0 5}$ & $\mathbf{2 0 1 0}$ \\
\hline Albania & 19.1 & 32.0 & 17.7 \\
\hline B and H & 71.6 & 70.6 & 39.7 \\
\hline Serbia & 48.3 & 57.5 & 41.5 \\
\hline Macedonia & 49.6 & 49.2 & 74.8 \\
\hline Montenegro & 47.1 & 42.8 & 51.9 \\
\hline Croatia & 48.4 & 36.3 & 34.8 \\
\hline
\end{tabular}

Table 9: Bonding social capital - family important in life

\begin{tabular}{|l|c|c|c|c|}
\hline \multirow{2}{*}{ Country } & $\mathbf{2 0 0 0}$ & $\mathbf{2 0 0 5}$ & \multicolumn{2}{|c|}{$\mathbf{2 0 1 0}$} \\
\cline { 2 - 5 } & $\begin{array}{c}\text { Family im- } \\
\text { portant in } \\
\text { life }\end{array}$ & $\begin{array}{c}\text { Family im- } \\
\text { portant in life }\end{array}$ & $\begin{array}{c}\text { Family } \\
\text { important } \\
\text { in life }\end{array}$ & $\begin{array}{c}\text { Concerned with } \\
\text { immediate fami- } \\
\text { ly }\end{array}$ \\
\hline Albania & 96.3 & 96.1 & 91.0 & 60.6 \\
\hline B and H & 97.2 & 98.7 & 76.8 & 47.5 \\
\hline Serbia & 88.6 & 92.0 & 86.1 & 43.9 \\
\hline Macedonia & 98.0 & 98.1 & 93.6 & 73.5 \\
\hline Montenegro & 88.3 & 92.3 & 92.0 & 56.7 \\
\hline Croatia & 85.3 & 78.7 & 77.1 & 39.9 \\
\hline
\end{tabular}

Source: WVS (2009), EVS (2011)

Informal social networks have the character of a safety net and are suitable for building personalized relationships of trust and reciprocity and mobilizing informal solidarity. Bridging ties are crucial for obtaining information, discovering new opportunities and advancing in society, while bonding ties strengthen relations within homogeneous groups and provide help and support to overcome problems of material and immaterial character. Based on presented data, it can be concluded that individuals who live in the Balkan countries highly value relations with friends and family and rely on their support during life. With the exception of Albania, in all the Balkan countries, about half of the respondents highly values relations with friends and acquaintances. In Croatia the data record decline in the importance of this kind of social relations over time, while in other countries, the percentage of respondents who rely on 
friends is higher than $40 \%$ in the latest period. The importance of bonding ties in the Balkans is very high, considering that over $90 \%$ of respondents declare that family is very important in life. The intensity of this kind of social relations is constant over time, as in all periods the percentage of respondents who place a great importance on family is high. A decrease of dependence on family ties is observed only in the last period, although still a high percentage of the population identify themselves as "very concerned" for the living conditions of their families.

Results of the analysis indicate that the citizens of Balkan countries in the difficult years of economic and political changes have turned to strengthening informal social ties and personalized trust, seeking safety in social niches composed of close relatives and friends. Thus, during the transition of the Balkan countries, creation of social capital was more directed towards strengthening informal networks, as an alternative to generalized trust, trust in institutions or formal participation. A slight decline in this type of social capital is recorded in the last period.

\subsection{Social norms - an indicator of civic consciousness}

As an integral element of cognitive social capital, social norms are related to specific attitudes of individuals and the characteristics of their behavior. The study of this element of social capital is important because social norms influence the behavior of individuals within a social group, and are considered an indicator of civic consciousness. Measuring this element of social capital is based on respondents' attitudes about the justification of certain actions that involve the neglect of social interest, such as claiming state benefits without legal entitlement, avoiding public transport fare, cheating on tax, accepting a bribe. Respondents' opinions are expressed on a scale of 1 to 10 , where 1 means that such behavior can never be justified, and 10 that such behavior is always justified.

Table 10. Justification of social actions (in \%)

\begin{tabular}{|l|c|c|c|c|c|c|c|c|c|c|c|c|}
\hline & \multicolumn{3}{|c|}{ Cheating on tax } & \multicolumn{3}{c|}{$\begin{array}{c}\text { Claiming govern- } \\
\text { ment benefits }\end{array}$} & \multicolumn{3}{c|}{ Accepting a bribe } & \multicolumn{3}{|c|}{$\begin{array}{c}\text { Avoiding public } \\
\text { transport fare }\end{array}$} \\
\hline Period & 2000 & 2005 & 2010 & 2000 & 2005 & 2010 & 2000 & 2005 & 2010 & 2000 & 2005 & 2010 \\
\hline Albania & 0.1 & 0.1 & 1.3 & 12.3 & 0.4 & 0.3 & 0.3 & 1.4 & 1.6 & 0.2 & 0.8 & 1.5 \\
\hline B and H & 0.8 & 1.7 & 3.7 & 0.1 & 0.6 & 1.5 & 0.1 & 0.5 & 1.0 & 1.8 & 1.0 & 5.1 \\
\hline Croatia & 5.5 & 3.9 & 3.9 & 4.3 & 1.1 & 1.1 & 1.3 & 1.7 & 0.6 & 11.3 & 7.3 & 7.7 \\
\hline Macedonia & 2.4 & 5.1 & 2.4 & 6.4 & 5.7 & 2.6 & 0.2 & 2.7 & 2.8 & 4.6 & 2.6 & 1.7 \\
\hline Montenegro & 2.6 & 1.7 & 2.7 & 1.8 & 1.4 & 3.0 & 0.3 & 0.4 & 0.5 & 3.5 & 1.7 & 5.2 \\
\hline Serbia & 2.6 & 1.7 & 1.6 & 1.8 & 1.4 & 1.6 & 0.3 & 0.4 & 0.6 & 3.5 & 1.7 & 4.3 \\
\hline \hline
\end{tabular}

Source: WVS (2009), EVS (2011) 
Golubović N et al.: A Comparative Analysis of Social Capital in the Western Balkan...

Table 10 shows the percentage of the population in the Balkan countries who believe that certain kinds of behavior can always be justified. The relatively low percentage of respondents who would be willing to always justify the violation of moral norms indicates a high degree of civic consciousness among the citizens of the Balkan countries. Relative willingness to tolerate nonpayment of public transport fare is present in most countries (the least problems with non-compliance to this rule have citizens of Croatia, Montenegro and Bosnia and Herzegovina), suggesting that this type of behavior is not considered too problematic. There is a slight increase in the average number of respondents who justify tax evasion, particularly in Croatia and Bosnia and Herzegovina. Claiming of state benefits is a form of behavior that is less tolerated in the countries under study, while the strictest attitudes of respondents are related to bribery. With respect to quantifying this segment of social capital it should be noted that the proclaimed norms may differ from actual behavior. Unfortunately, the used data sources only include indicators that describe the norms rather than the actual behavior.

\subsection{The intensity of political engagement of citizens in the Western Balkans}

At the level of society as a whole, it is expected that greater participation in public life results in better functioning of democracy, and has positive effects on economic development, as active citizens can influence the improvement of the functioning of formal institutions. They can do this in different ways one of them is through various forms of political engagement (which is closely related to linking social capital). Together with social norms, political engagement is generally considered a component of social capital, which is considered as civic engagement. Measuring this component of social capital is based on determining of general interest in politics among the respondents, as well as their active participation in political events.

Table 11. Interest in politics (in \%)

\begin{tabular}{|l|c|c|c|c|c|c|c|c|c|}
\hline & \multicolumn{4}{|c|}{$\begin{array}{c}\text { Often discusses political } \\
\text { matters with friends }\end{array}$} & \multicolumn{3}{c|}{$\begin{array}{c}\text { Politics very important } \\
\text { in life }\end{array}$} & \multicolumn{3}{c|}{$\begin{array}{c}\text { Following politics in } \\
\text { the news every day }\end{array}$} \\
\hline Period & 2000 & 2005 & 2010 & 2000 & 2005 & 2010 & 2000 & 2005 & 2010 \\
\hline Albania & 19.6 & 18.2 & 12.3 & 3.8 & 8.3 & 3.1 & $/$ & 31.4 & 33.7 \\
\hline B and H & 20.8 & 13.1 & 13.6 & 12.8 & 11.0 & 8.2 & $/$ & 30.2 & 22.4 \\
\hline Croatia & 17.9 & 18.6 & 8.2 & 5.9 & 4.5 & 3.3 & $/$ & 52.5 & 30.8 \\
\hline Macedonia & 15.3 & 28.7 & 18.6 & 10.2 & 14.1 & 16.8 & $/$ & 56.2 & 27.1 \\
\hline Montenegro & 12.7 & 16.7 & 6.0 & 7.0 & 5.3 & 4.4 & $/$ & 37.5 & 22.3 \\
\hline Serbia & 12.7 & 16.7 & 12.8 & 7.0 & 5.3 & 6.1 & $/$ & 37.5 & 27.7 \\
\hline \hline Average & 16.5 & 18.7 & 11.9 & 7.8 & 8.1 & 7.0 & $/$ & 40.9 & 27.3 \\
\hline \hline
\end{tabular}

Source: WVS (2009), EVS (2011) 
Golubović N et al.: A Comparative Analysis of Social Capital in the Western Balkan...

Interest in politics is determined based on respondents' answers to questions about how much politics is important in life, how often they discuss political issues with friends and how often they follow politics in the news (Table 11). Political activism includes individual's willingness to sign petitions, join boycotts and participate in legal demonstrations and strikes (Table 12).

Table 12. Political activism (\% of respondents that have participated in the following forms of political action)

\begin{tabular}{|l|c|c|c|c|c|c|c|c|c|c|c|c|}
\hline & \multicolumn{3}{|c|}{ Signing a petition } & \multicolumn{3}{|l|}{ Joining in boycotts } & \multicolumn{3}{c|}{$\begin{array}{c}\text { Attending lawful } \\
\text { demonstrations }\end{array}$} & \multicolumn{3}{|c|}{$\begin{array}{c}\text { Joining unofficial } \\
\text { strikes }\end{array}$} \\
\hline Period & 2000 & 2005 & 2010 & 2000 & 2005 & 2010 & 2000 & 2005 & 2010 & 2000 & 2005 & 2010 \\
\hline Albania & 27.3 & 22.4 & 22.4 & 11.6 & 5.6 & 9.7 & 19.0 & 24.6 & 12.1 & 0.3 & 2.1 & 2.9 \\
\hline B and H & 22.0 & 22.0 & 23.7 & 8.8 & 6.7 & 6.9 & 9.0 & 9.2 & 6.8 & 5.8 & 3.6 & 3.2 \\
\hline Croatia & 42.7 & 35.0 & 44.5 & 4.7 & 6.4 & 9.7 & 6.9 & 7.0 & 8.8 & 6.6 & 2.9 & 4.6 \\
\hline Macedonia & 15.4 & 26.5 & 38.8 & 8.0 & 13.4 & 22.6 & 10.8 & 17.6 & 21.1 & 2.5 & 4.9 & 9.7 \\
\hline Montenegro & 18.8 & 26.7 & 19.2 & 6.8 & 17.7 & 8.0 & 8.2 & 22.3 & 10.0 & 4.7 & 6.3 & 4.6 \\
\hline Serbia & 18.8 & 26.7 & 23.2 & 6.8 & 17.7 & 11.4 & 8.2 & 22.3 & 14.2 & 4.7 & 6.3 & 5.3 \\
\hline \hline Average & 24.2 & 26.6 & 28.6 & 7.8 & 11.2 & 11.4 & 1.4 & 17.2 & 12.2 & 4.1 & 4.3 & 5.1 \\
\hline \hline
\end{tabular}

Source: WVS (2009), EVS (2011)

The citizens of the Balkan countries express their interest in politics primarily through daily following of political issues in the news. In some countries (Croatia, Macedonia), over $50 \%$ of respondents follows political news every day. In the second place is discussing politics with friends, while the lowest number of respondents claims that politics is very important in life. If the interest in politics in the Balkan countries is observed over time, one can identify a pattern of changes - in the second five-year period, interest in politics has increased, as measured by all three indicators, and in recent years there has been a sharp decline in all forms of interest. However, this does not apply to active participation of citizens in political affairs. In fact, nearly all forms of political activism (except participation in the demonstrations) over time are more intensely present in the Balkans. The citizens of these countries most frequently sign petitions, but are also active in demonstrations, strikes and boycotts. The intensity of political engagement in the literature is often linked to the availability of social capital (Coleman, 1988; Fine, 2010). Specifically, it is expected that social capital, which is accumulated in social networks and different structures of social relations between individuals, encourages some positive activities that would be lacking in the absence of social capital. In this regard, it is emphasized that social capital influences the strengthening of capacity for political action and thus increases the likelihood of individuals' political engagement. Therefore, we can say that the recorded level of political en- 
Golubović N et al.: A Comparative Analysis of Social Capital in the Western Balkan...

gagement in the Balkan countries is a reflection of the presence of a certain level of social capital.

\section{Conclusions}

Theoretical knowledge of the effects of social capital on economic and social development is not universally applicable and needs to be tested in a specific social and institutional environment. Apart from the clear differences between the countries of the Western Balkans, their common feature are decades spent in a specific social and economic system, which some theorists hold responsible for the dissolution of generalized trust, citizens' trust in government and its institutions, as well as all forms of civil society. After the regime shift, these societies are characterized not only by very low levels of generalized trust and trust in institutions, as well as the poor level of civil society development, but also by a tendency of existence of informal networks of social relations created during the pre-transformation period to slip easily into something that could be marked as negative social capital. Negative social capital represents all kinds of social networking aimed at activities such as corruption, criminal, grey economy, blocking the reform process, rent-seeking. Finally, the events after the beginning of the transition, which relate to extensive institutional changes in states facing the lack of legitimacy, contributed to the failure of the expected accumulation processes of positive elements of social capital, such as generalized trust, trust in institutions and formal networking. At the same time, there has been no weakening of strong informal networks as mechanisms designed as a substitution of formal systems in conditions of uncertainty and economic difficulties. Thus, the specificity of social capital in the Balkans could shortly be described as a critical lack of trust in institutions and generalized trust, which stands in the way of improving the economic and institutional efficiency, as well as strong informal networks (the so-called network capital), which in most cases hinder the reform process.

The results of the analysis point to the low level of generalized trust, trust in a number of formal institutions and weak intensity of formal networking within civil society organizations. Also, the analysis shows reducing levels of generalized trust over time. Average trust in institutions is, without exception, below the average of developed countries, and even more alarming is its declining over time, and the fact that citizens trust the least those institutions whose main function is the implementation of reforms - government, parliament, political parties, while they still trust traditional institutions - church and army. Even though a positive trend is noticed in the membership in social organizations, citizens of Balkan countries still do not engage much in this kind of associations. On the other hand, they are intensively relying on informal contacts and ties within primary relationships (family and friends), with an extremely high 
Golubović N et al.: A Comparative Analysis of Social Capital in the Western Balkan...

percentage of those who rely on this type of social networks in everyday life. This study has shown that the creation of social capital in the Balkan countries was directed towards strengthening the informal networks as an alternative to the generalized trust, trust in institutions or formal participation.

\section{References}

Adam, F., Makarovic, M., Roncevic, B., \& Tomsic, M. (2004). The Challenges of Sustained Development: The Role of Socio-Cultural Factors in East Central Europe. Budapest and New York: Central European University Press.

Coleman, J. (1988). Social Capital in the Creation of Human Capital. The American Journal of Sociology 94 (5), 95-120.

EVS (2011), European Values Study 2008: Integrated Dataset (EVS 2008). Gesis Datenarchiv, Köln. ZA4800, Datafile Version 3.0.0, doi:10.4232/1.11004.

Evans, P. (1996). Government Action, Social Capital and Development: Reviewing the Evidence on Synergy. World Development, 24(6), 1119-1132.

Fine, B. (2010). Theories of Social Capital: Researchers Behaving Badly. Pennsylvania State University: Pluto Press.

Gambetta, D. (1998). Trust, the Social Virtues and the Creation of Prosperity, New York: Free Press.

Glaeser, E.L., Laibson, D., \& Sacerdote, B. (2000). The Economic Approach to Social Capital. NBER Working Paper No. 7728. Retrieved from The National Bureau of Economic Research.

http://www.nber.org/papers/w7728

Granovetter, M. (1973). The Strength of the Weak Ties. American Journal of Sociology, 78(6), 1360-1380.

Grootaert, C., Bastelaer, T. (2002). Understanding and measuring social capital. A synthesis of findings and recommendations from the social capital initiative. Retrieved from the World Bank. http://www.worldbank.org/library

Hanifan, L.J. (1920). The Community Center. Boston: Silver, Burdett and Co.

Knack, S., \& Keefer, P. (1997). Does Inequality Harm Growth Only in Democracies? American Journal ofPolitical Science, 41(1), 323-32.

Milošević Đ. J. (2012). Parametar socijalnog kapitala: poverenje građana Srbije u političke institucije. Srpska politička misao, 4: 197-212.

Narayan, D., \& Cassidy, M.F. (2001). A dimensional approach to measuring social capital: development and validation of a social capital inventory. Current Sociology, 49 (2), 59-102.

Oorshot, W., \& Arts, W. (2005). Social Capital of European Welfare States: the Crowding Out Hypothesis Revisited. Journal of European Social Policy, 15 (1), 5-26. 
Golubović $N$ et al.: A Comparative Analysis of Social Capital in the Western Balkan...

Paldam, M. (2000). Social Capital: One or Many? Definition and Measurement. Journal of Economic Surveys, 14(5), 629-653.

DOI: $10.1111 / 1467-6419.00127$

Paldam, M., \& Svedsen G.T. (2000). An essay on social capital: Looking for the fire behind the smoke. European Journal of Political Economy, 16(2): 339-366.

Paldam, M., \& Svedsen G.T. (2001). Missing social capital and the transition in Eastern Europe. Journal for Institutional Innovation, Development and Transition 5: 21-33.

Putnam, R.D., Leonardi, R., \&Nanetti, R. (1993). Making Democracy Work: Civic Traditions in Modern Italy. Princeton: Princeton University Press.

Putnam, R.D. (1995). Bowling alone: America's declining social capital. Journal of Democracy, 6(1), 65-78.

Putnam, R. D. (2008 [1995]). Kuglati sam. Slom i obnova američke zajednice, Novi Sad: Mediterran Publishing.

Rothstein, B. (2001). Social Capital in the Social Democratic Welfare State. Politics and Society, 29 (2), 207-241.

Rothstein, B., Stolle, D. (2002). How Political Institutions Create and Destroy Social Capital: an Institutional Theory of Generalized Trust. Paper prepared for the 98th Meeting of the American Political Science Association in Boston, MA, August 29-September 2, 2002. Retrieved from: http://upload.mcgill.ca/politicalscience/011011RothsteinB.pdf

Soroka, S. N., Helliwell, J.F., \& Johnston, R. (2003). Measuring and Modelling Trust. In: F. Kay \& R. Johnston (Eds.), Diversity, Social Capital and the Welfare State (pp. 95-132). Vancouver, BC: University of British Columbia Press.

Uphoff, N. (2000). Understanding Social Capital: Learning from the Analysis and Experiences of Participation. In P. Dasgupta \& I. Seregeldin (Eds), Social Capital: A Multifaceted Perspective (pp. 215-252). Washington DC: World Bank.

Woolcock, M. (1998). Social capital and economic development: towards a theoretical synthesis and policy framework. Theory and Society, 27, 151208.

WVS (2009). World Values Survey 1981-2008 Official Aggregate v.20090901. 